\title{
Plasma Kisspeptin Levels in Hypothyroidism and Premature Newborns
}

\author{
A Kaya ${ }^{1}$, Z Orbak $^{1}$, H Polat ${ }^{2}$, E Şebin ${ }^{2}$, İ Polat ${ }^{1}$, E Gülfidan $^{1}$
}

\begin{abstract}
Aim: The purpose of this study was to determine kisspeptin levels in healthy newborns and to show whether there is significant difference in kisspeptin levels between males and females in the hypothyroid newborns and healthy term newborns.

Subjects and Methods: This study was performed prospectively. The newborns were admitted to the Erzurum Atatürk University Medical Faculty Research Hospital Pediatric Endocrinology and Neonatal polyclinic between July and November 2014. In hypothyroid newborns, blood sampling was performed 14-30 days after birth. Twelve hypothyroid newborns, 14 premature newborns and 36 term newborns (as control group) were included. Plasma specimens were investigated using enzyme-immune assay. Significance was set at $\mathrm{p}<0.01$.

Results: In the hypothyroid group, minimum kisspeptin level was $0.48 \mathrm{ng} / \mathrm{mL}$, maximum value $0.78 \mathrm{ng} / \mathrm{mL}$, mean $0.61 \pm 0.08 \mathrm{ng} / \mathrm{mL}$. In the premature group, minimum kisspeptin level was $0.27 \mathrm{ng} / \mathrm{mL}$, maximum level $0.97 \mathrm{ng} / \mathrm{mL}$, mean $0.64 \pm 0.17 \mathrm{ng} / \mathrm{mL}$. In the control group of healthy term newborns, minimum kisspeptin level was $0.25 \mathrm{ng} / \mathrm{mL}$, maximum level $0.99 \mathrm{ng} / \mathrm{mL}$, mean $0.49 \pm 0.17 \mathrm{ng} / \mathrm{mL}$. A statistically significant difference in kisspeptin levels was determined between the hypothyroid and the control groups $(\mathrm{p}=0.004)$. There was also a significant difference in kisspeptin levels between the premature and the control groups $(\mathrm{p}=0.010)$.

Conclusion: Kisspeptin may be indicating various play role clarification in the newborn period of various changes. A statistically significance in kisspeptin levels was determined between the hypothyroid and the control groups and also between the premature and the control groups. Kisspeptin levels may point to various clinical states in the newborn.
\end{abstract}

Keywords: Hypothyroidism, kisspeptin, newborn premature

\section{Niveles Plasmáticos Kisspeptina en Kipotiroidismo y los Recién Nacidos Prematuros} A Kaya ${ }^{1}$, Z Orbak $^{1}$, H Polat $^{2}$, E Şebin ${ }^{2}$, İ Polat ${ }^{1}$, E Gülfidan ${ }^{1}$

\begin{abstract}
RESUMEN
Objetivo: El propósito de este estudio fue determinar los niveles de kisspeptina en recién nacidos sanos y mostrar si hay diferencia significativa en los niveles de kisspeptina entre machos y hembras en los recién nacidos hipotiroideos y los recién nacidos a término sanos.

Sujetos y métodos: Este estudio fue realizado de manera prospectiva. Los recién nacidos fueron admitidos en el Policlínico de Neonatología y Endocrinología Pediátrica del Hospital de Investigación de la Facultad de Medicina de la Universidad de Erzurum Atatürk entre julio y noviembre de 2014. En recién nacidos hipotiroideos, la muestra de sangre fue realizada 14-30 dias después del nacimiento. Se incluyeron doce recién nacidos hipotiroideos, 14 recién nacidos prematuros y 36 recién nacidos a término (como grupo de control). Las muestras de plasma fueron investigadas usando el ensayo inmunoenzimático. Significación se fijó en $\mathrm{p}<0.01$.

Resultados: En el grupo hipotiroideo, el nivel mínimo de kisspeptina fue $0.48 \mathrm{ng} / \mathrm{mL}$, el valor máximo 0.78 $\mathrm{ng} / \mathrm{mL}$, y el nivel medio $0.61 \pm 0.08 \mathrm{ng} / \mathrm{mL}$. En el grupo prematuro, el nivel mínimo de kisspeptina fue $0.27 \mathrm{ng} / \mathrm{mL}$, el nivel máximo $0.97 \mathrm{ng} / \mathrm{mL}$, y el nivel medio $0.64 \pm 0.17 \mathrm{ng} / \mathrm{mL}$ En el grupo control de recién nacidos a término sanos, el nivel mínimo de kisspeptina fue $0.25 \mathrm{ng} / \mathrm{mL}$, el nivel máximo $0.99 \mathrm{ng} / \mathrm{mL}$, y el nivel medio $0.49 \pm 0.17 \mathrm{ng} / \mathrm{mL}$. Se determinó una diferencia estadísticamente significativa en los
\end{abstract}

From: ${ }^{1}$ Department of Pediatric Endocrinology and ${ }^{2}$ Department of Biochemistry, Ataturk University, Faculty of Medicine, Erzurum, Turkey.
Correspondence: Dr A Kaya, Department of Pediatric Endocrinology, Faculty of Medicine, Ataturk University, Erzurum, Turkey. Fax: +4422361301, e-mail: avnikaya@gmail.com 
niveles de kisspeptina entre el grupo de hipotiroidismo y el grupo de control $(\mathrm{p}=0.004)$. También hubo una diferencia significativa en los niveles de kisspeptina entre el grupo de prematuros y el grupo de control $(\mathrm{p}=0.010)$.

Conclusión: La kisspeptina puede desempeñar varios papeles a la hora aclarar diversos cambios en el periodo neonatal. Se determinó una diferencia estadisticamente significativa en los niveles de kisspeptina entre el grupo de hipotiroidismo y el grupo de control y también entre el grupo de prematuros y el grupo de control. Los niveles de kisspeptina pueden indicar diversos estados clínicos en el recién nacido.

Palabras claves: Hipotiroidismo, kisspeptina, recién nacido, prematuro

West Indian Med J 2016; 65 (3): 526

\section{INTRODUCTION}

Humans go through a mini-puberty period that begins in fetal life and this continues in the newborn period and until middle infancy. The period when gender hormone levels are high, such as puberty (1). The hypothalamus-pituitary-gonadal axis is transiently activated during the first months of postnatal life (2). Kisspeptin is a very powerful neuropeptide that stimulates release of luteinizing hormone (LH) and follicle stimulating hormone (FSH) from the pituitary and LH exhibits its effect via gonadotropin-releasing hormone [GnRH] (3). Kisspeptin is regarded as the major regulator of reproductive functions and onset of puberty $(4,5)$ by its direct action on gonadotrophs or through GnRH neurons $(6,7)$.The purpose of this study was to determine kisspeptin levels in healthy newborns and to show whether there is significant difference between kisspeptin levels in females and males hypothyroid newborns and healthy term newborns.

\section{SUBJECTS AND METHODS}

This study was performed prospectively. The newborns admitted to the Erzurum Atatürk University Medical Faculty Research Hospital Pediatric Endocrinology and Neonatal polyclinic between July and November 2014. Blood sampling in hypothyroid newborns was performed in hypothyroid newborns 14-30 days after birth. Twelve hypothyroid newborns (7 females and 5 males), 14 premature newborns ( 8 females and 6 males) and 36 newborns (15 females and 21 males) as the control group were included. The newborns with any disease or congenital anomaly and with chronic disease of the mothers were excluded. Follicle stimulating hormone (normal: male $0.16-4.1 \mathrm{mIU} / \mathrm{mL}$, female $0.24-14.2 \mathrm{mIU} / \mathrm{mL})$, LH (normal $0.02-7.0 \mathrm{mIU} / \mathrm{mL}$ ), free T4 (FT4) (normal $0.61-1.4 \mathrm{ng} / \mathrm{dL}$ ) and thyroid stimulating hormone [TSH] (normal 0.6-7 $\mu \mathrm{IU} / \mathrm{mL}$ ) were investigated in the blood specimens. Once informed consent had been received, newborns' prenatal and postnatal histories were taken and physical examinations was performed by same paediatric endocrinologist. Two milliliters of blood collected using routine venous blood collection methods was placed into tubes containing $\mathrm{K}_{2}$ EDTA. Blood samples were centrifuged and stored at $-80^{\circ} \mathrm{C}$. Plasma specimens were gradually thawed the day before they were investigated and homogenized by vortexing at room temperature. Plasma specimens were investigated using enzyme-immune assay (EIA) following the manufacturer's instructions at the Atatürk University Hospital Biochemistry Department. (KiSS1 (112-121) Amide/Kisspeptin-10/Metastin (45-54) Amide (Human) EIA KIT, Phoenix Pharmaceuticals Inc). Kisspeptin levels were expressed as nanograms/milliliter.

\section{Statistical analysis}

The minimum, maximum and mean values with standard deviations were determined for the patient's bodyweight, length and postnatal age SSPE 20 for Windows was used for data analysis. The Kolmogorov-Smirnov test was used to determine whether newborns' kisspeptin values were normally distributed. Since cases' kisspeptin values were normally distributed, the independent-samples $t$-test was used. Spearman correlation analysis was performed between kisspeptin and other parameters. Significance was set at $p<0.01$. The study was approved by our University Ethics Committee (Date 3.7.2014 Session: 7 Decision number: 1).

\section{RESULTS}

Patients' demographic and laboratory data are shown in Table 1. The youngest baby in terms of gestational age at birth in our premature group was 35 weeks old and the oldest 37 weeks old; mean gestational age value was $36.36 \pm 0.63$. In the hypothyroid group, minimum kisspeptin level was $0.48 \mathrm{ng} / \mathrm{mL}$, maximum value was $0.78 \mathrm{ng} / \mathrm{mL}$, mean was $0.61 \pm 0.08$ $\mathrm{ng} / \mathrm{mL}$. In the premature group, minimum kisspeptin level was $0.27 \mathrm{ng} / \mathrm{mL}$, maximum level was $0.97 \mathrm{ng} / \mathrm{mL}$, mean was 0.64 $\pm 0.17 \mathrm{ng} / \mathrm{mL}$. In the control group of healthy term newborns, minimum kisspeptin level was $0.25 \mathrm{ng} / \mathrm{mL}$, maximum level was $0.99 \mathrm{ng} / \mathrm{mL}$, mean was $0.49 \pm 0.17 \mathrm{ng} / \mathrm{mL}$. A statistical significance in kisspeptin levels was determined between the hypothyroid and the control groups $(p=0.004)$. There was also a significance in kisspeptin levels between the premature and the control groups $(p=0.01)$. Although a negative correlation was determined between kisspeptin and bodyweight $(p$ $=0.005, \mathrm{r}:-0.352)$, no correlation was determined with length $(p=0.052, \mathrm{r}:-0.248)$, age $(p=0.456, \mathrm{r}: 0.096), \mathrm{FSH}(p=0.167$, r: 0.179), LH ( $p=0.717$, r: -0.047$),$ TSH $(p=0.308, \mathrm{r}: 0.132)$ or FT4 ( $p=0.355$, r: -0.119$)$. 
Table: Demographic and laboratory data of patients

\begin{tabular}{|c|c|c|c|c|c|}
\hline Groups & Parameter & Minimum & Maximum & Mean & $\begin{array}{l}\text { Standard } \\
\text { deviation }\end{array}$ \\
\hline \multirow[t]{7}{*}{ Hypothyroidism (n:12) } & Weight (kg) & 3.1 & 4.5 & 3.72 & 0.44 \\
\hline & Length $(\mathrm{cm})$ & 49 & 59 & 52.25 & 2.59 \\
\hline & Age (day) & 15 & 36 & 21.67 & 6.03 \\
\hline & FSH & 0.18 & 19.80 & 7.75 & 6.91 \\
\hline & LH & 0.07 & 5.20 & 1.92 & 1.93 \\
\hline & FT4 & 0.08 & 1.13 & 0.47 & 0.30 \\
\hline & TSH & 21.70 & 100.00 & 75.84 & 26.67 \\
\hline \multirow[t]{7}{*}{ Premature (n:14) } & Weight (kg) & 2.0 & 3.5 & 2.87 & 0.44 \\
\hline & Length $(\mathrm{cm})$ & 42 & 53 & 47.93 & 3.17 \\
\hline & Age (day) & 13 & 30 & 21.14 & 5.39 \\
\hline & FSH & 0.74 & 69.60 & 19.60 & 24.15 \\
\hline & LH & 0.03 & 23.60 & 4.83 & 7.43 \\
\hline & FT4 & 0.89 & 1.91 & 1.18 & 0.24 \\
\hline & TSH & 1.07 & 6.20 & 2.75 & 1.35 \\
\hline \multirow[t]{7}{*}{ Control (n:36) } & Weight (kg) & 2.7 & 5.8 & 4.19 & 0.64 \\
\hline & Length $(\mathrm{cm})$ & 47 & 56 & 52.06 & 1.67 \\
\hline & Age (day) & 14 & 30 & 21.36 & 4.39 \\
\hline & FSH & 0.60 & 13.40 & 3.73 & 2.98 \\
\hline & LH & 0.02 & 15.90 & 3.14 & 3.18 \\
\hline & FT4 & 0.77 & 1.44 & 1.15 & 0.17 \\
\hline & TSH & 0.75 & 6.40 & 3.10 & 1.62 \\
\hline
\end{tabular}

Follicide stimulating hormone: FSH: luteinizing hormone:LH; free thyroxine (FT4); gonadotropin-releasing hormone: $\mathrm{GnRH}$; thyroid stimulating hormone: TSH

\section{DISCUSSION}

Kisspeptin is synthesized from the arcuate nucleus in the hypothalamus and neurons in the anteroventral periventricular nucleus (3). Parallel changes in GnRH pulses also accompany an increase in kisspeptins, and an association has been shown between an increase in kisspeptin and pubertal changes in GnRH pulses. Central or peripheral administration of kisspeptin in an animal model has been shown to stimulate the hypothalamus-pituitary-gonadal axis and to increase secretion of FSH and $\mathrm{LH}(3,8,9)$. Kisspeptins in the peripheral circulation function by passing the blood-brain barrier and affecting GnRH release (4). Observations show that kisspeptins in the circulation are physiologically significant and play a role in the regulation of the hypothalamus-pituitary-gonadal axis in many species, including humans (10). Postnatal hypothalamus pituitary gonadal axis activation in infancy is increased in premature boys compared with healthy boys (11). Kisspeptin may mediate this situation. Kisspeptin levels were significantly higher in premature and hypothyroid newborns compared to healthy newborns may be due to kisspeptin increasing release of FSH and LH by increasing the hormone GnRH. In our study, FSH levels were higher in the hypothyroid and premature newborns than in the control group. Luteinizing hormone levels were higher in the premature group compared to the control group, while LH levels were only low in the hypothyroid group. Low LH in hypothyroid conditions has also been confirmed in previous studies. Webster et al and Anderson et al both emphasized that thyroid hormones are necessary for GnRH and LH pulsatility $(12,13)$. Other studies show that action of thyroid hormone on GnRH neurons as co-expression of thyroid hormone receptors in GnRH neurons has been pre- viously demonstrated by Parhar et al and Jansen et al $(14,15)$. Ogawa et al (16) have made the most comprehensive study that showing the relationship between kisspeptin and hypothyroidism. In the literature, it is the only study showing the relationship between kisspeptin and thyroid hormones. Their study shows that GnRH1 may be directly regulated through thyroid hormone, while the regulation of kiss 2 by triiodothyronine is more likely to be indirect. They cloned kiss 2 gene in a fish race. They showed that real-time polymerase chain reaction revealed that administration of triiodothyronine significantly increased the amount of kiss 2 and gnrh 1 mRNA levels 24 hours after administration when compared with control fish, while the genes were suppressed under hypothyroid condition with methimazole treatment (16).

Kisspeptin levels were $0.64 \pm 0.17 \mathrm{ng} / \mathrm{mL}$ in premature newborns, $0.61 \pm 0.08 \mathrm{ng} / \mathrm{mL}$ in hypothyroid newborns and $0.49 \pm 0.17 \mathrm{ng} / \mathrm{mL}$ in healthy newborns. Different studies have reported plasma kisspeptin levels of $2.96 \pm 1.21 \mathrm{ng} / \mathrm{dL}$ in girls aged 3-8 years (17), $1.68 \pm 0.95 \mathrm{ng} / \mathrm{mL}$ in children aged 5-9 years (18), $0.77 \mathrm{ng} / \mathrm{mL}$ in males aged $9-18$ years and $6.24 \pm$ $2.042 \mathrm{ng} / \mathrm{mL}$ in adults aged $18-40$ years (19), higher than the levels determined in our study. This may be due to our patients being in the newborn period. In addition, this finding shows that kisspeptin is at lower levels in the newborn period and increases with age.

One study reported no significant correlation between kisspeptin and anthropometric parameters [length and weight] (18). In our study, however, a weak negative correlation was determined between kisspeptin levels and bodyweight.

This is the first study which investigates kisspeptin levels in hypothyoridic, premature and healthy newborns. 
Kisspeptin is a newly described molecule whose effects on puberty and gynaecomastia have recently been revealed. Various changes that occur in the body in the newborn period have still not been fully clarified. Kisspeptin may be play role of various changes in the clarification in the newborn period.

In conclusion, statistically significant kisspeptin levels are determined between the hypothyroid and the control groups and also statistically significant kisspeptin levels were found between the premature and the control groups.

\section{REFERENCES}

1. Kurtoğlu S, Baştuğ O. Mini puberty and its interpretation. Turk Ped Ars 2014; 49: 186-91.

2. Zivkovic D, Fratric I. Disturbances of sperm maturation and minipuberty: is there a connection? Biomed Res Int 2014; 2014: 912746.

3. Mikkelsen JD, Bentsen AH, Ansel L, Simonneaux V, Juul A. Comparison of the effects of peripherally administered kisspeptins. Regul Pept 2009; 152: 95-100.

4. Tena-Sempere M. GPR54 and kisspeptin in reproduction. Hum Reprod Update 2006; 12: 631-9.

5. Dungan HM, Clifton DK, Steiner RA. Minireview: kisspeptin neurons as central processors in the regulation of gonadotropin-releasing hormone secretion. Endocrinology 2006; 147: 1154-8.

6. Gottsch ML, Cunningham MJ, Smith JT, Popa SM, Acohido BV, Crowley WF et al. A role for kisspeptins in the regulation of gonadotropin secretion in the mouse. Endocrinology 2004; 145: 4073-7.

7. Thompson EL, Patterson M, Murphy KG, Smith KL, Dhillo WS, Todd JF et al. Central and peripheral administration of kisspeptin-10 stimulates the hypothalamic-pituitary-gonadal axis. J Endocrinol 2004; 16: 850-8.

8. Dhillo WS, Chaudhri OB, Patterson M, Thompson EL, Murphy KG, Badman MK et al. Kisspeptin-54 stimulates the hypothalamic-pituitary gonadal axis in human males. J Clin Endocrinol Metab 2005; 90: 6609-15.
9. Roseweir AK, Kauffman AS, Smith JT, Guerriero KA, Morgan K, Pielecka-Fortuna JT al. Discovery of potent kisspeptin antagonists delineate physiological mechanisms of gonadotropin regulation. J Neurosci 2009; 29: 3920-9.

10. Bianco SD. A potential mechanism for the sexual dimorphism in the onset of puberty and incidence of idiopathic central precocious puberty in children: sex-specific kisspeptin as an integrator of puberty signals. Front Endocrinol (Lausanne) 2012; 3: 149.

11. Kuiri-Hanninen T, Seuri R, Tyrvainen E, Turpeinen U, Hamalainen E, Stenman UH, et al. Increased activity of the hypothalamic-pituitarytesticular axis in infancy results in increased androgen action in premature boys. J Clin Endocrinol Metab 2011; 96: 98-105.

12. Anderson GM, Connors JM, Hardy SL, Valent M, Goodman RL. Thyroid hormones mediate steroid-independent seasonal changes in luteinizing hormone pulsatility in the ewe. Biol Reprod 2002; 66: 701-6.

13. Webster JR, Moenter SM, Barrell GK, Lehman MN, Karsch FJ. Role of the thyroid gland in seasonal reproduction. III. Thyroidectomy blocks seasonal suppression of gonadotropin-releasing hormone secretion in sheep. Endocrinology 1991; 129: 1635-43.

14. Parhar IS, Soga T, Sakuma Y. Thyroid hormone and estrogen regulate brain region-specific messenger ribonucleic acids encoding three gonadotropin-releasing hormone genes in sexually immature male fish, Oreochromis niloticus. Endocrinology 2000; 141: 1618-26.

15. Jansen HT, Lubbers LS, Macchia E, DeGroot LJ, Lehman MN. Thyroid hormone receptor (alpha) distribution in hamster and sheep brain: colocalization in gonadotropin-releasing hormone and other identified neurons. Endocrinology 1997; 138: 5039-47.

16. Ogawa S, Ng KW, Xue X, Ramadasan PN, Sivalingam M, Li S et al. Thyroid hormone upregulates hypothalamic kiss2 gene in the male Nile Tilapia, oreochromis niloticus. Front Endocrinol (Lausanne) 2013; 4: 184.

17. Akinci A, Cetin D, Ilhan N. Plasma kisspeptin levels in girls with premature thelarche. J Clin Res Pediatr Endocrinol 2012; 4: 61-5.

18. Ersoy B, Yazici P, Yilmaz H, Onur E. Changes in pubertal hormones, neurotransmitters and sleep patterns during sleep in girls with precocious puberty. Int J Pediatr Endocrinol. 2013; 2013 (Suppl 1): P68.

19. Kavvasoglu S, Ozkan ZS, Kumbak B, Simsek M, Ilhan N. Association of kisspeptin-10 levels with abortus imminens: a preliminary study. Arch Gynecol Obstet 2012; 285: 649-53. 